\title{
ResearchOnline@JCU
}

This is the Accepted Version of:

Taylor, Cheryl (2012) Book review of "Interpreting Francis and Clare of Assisi: from the middle ages to the present" edited by Constant J. Mews and Claire Renkin, Broughton Publishing, Mulgrave, VIC, Australia. Parergon, 29 (1). pp. 233-235.

http://dx.doi.org/10.1353/pgn.2012.0012 
Mews, Constant J. and Claire Renkin, eds, Interpreting Francis and Clare of Assisi: From the Middle Ages to the Present, Melbourne, Broughton Publishing, 2010; paperback; pp. xvi, 416; 39 colour illustrations; R.R.P. AU\$89.95; ISBN 9780980663464.

This cross-disciplinary collection stems from a conference at the Yarra Theological Union in November 2009, one of several events held worldwide to celebrate the eighth centenary of the founding of the Franciscan Order. Meticulously and imaginatively printed and presented, the volume reaffirms the art of making fine books. The essays, together with a splendid gathering of coloured plates, trace the impact of Franciscan ideas from their beginnings into the contemporary world, encompassing countries as diverse as Italy, England, France, Ireland, Bohemia, Egypt and Australia. The book reasserts Francis and Clare's message of strenuous self-giving and simple living as a powerful response to twenty-firstcentury conflicts and disasters.

Like Christianity as a whole, Franciscan history embodies the paradox of a movement built on love for and identification with the poor, which has deviated too readily into oppression, hypocrisy and corruption. This collection counters the research effort that has been put into medieval and Renaissance anti-fraternal satire by recalling the challenge that Franciscan ideals in their purity have always posed to capitalist values. In seeking, in imitation of the founders, to implant caritas as the leading aspiration for the active and contemplative lives of individuals, Franciscan traditions are potentially more radical than any left-wing ideology.

Accordingly, several essays in this collection focus on Franciscans' confrontations with economic determinism and papal authority. Drawing on Francis' and Clare's authenticated writings and other early sources, Jacques Dalarun delineates each saint's basic iconoclasm: '[Francis] overcomes the divisions of social, cultural and sexual categories by subverting them, turning them topsy-turvy. [Clare] ignores them, haughtily. In each individual, beginning with Francis, she sees immediately the transparency of Christ'. (p. 11). A study by Michael Cusato OFM delves into the early Friars' relationship to money, reviled as turpe lucrum, stercus, and serpens. Francis responded to the Gospel teachings on money's power to corrupt and on poverty as the path to perfection at the historical moment when coin and credit first infiltrated European economic life. The fierce renunciation of money in his first Rule, the Regula non bullata (1208-21), recognised 'a terrible and devastating social reality'-'Money...as it was experienced by the common folk of central Italy, including Assisi, was an instrument of exploitation used by the powerful to gain profit for themselves at 
the expense of the rest of the population, most especially the daily labourer, the vulnerable and the poor' (pp. 21-22). Not much has changed!

Other essays explore historical tensions, many of them creative, within and beyond early Franciscan thought and institutions. Of these, Anne M. Scott's study traces the paradox of Lady Poverty as the greatest evil yet a liberating Christian virtue in selected medieval literary works. Peta Hills OSC examines Clare's new concept of religious life in her Forma Vitae (1253), as enclosed, yet with permeable boundaries for working with the poor. She quotes the Clarissan view, astonishing to many, that poverty is simultaneously privilege and freedom (p. 115). Essays by Julie-Ann Smith and Robert Curry explore inner uncertainties and outer conflicts generated by the Clarissan sisters' renunciation of property. Janice Pinder's analysis of French verse translations of Thomas of Celano's Vita Prima exemplifies the role of Franciscan idealism in popular culture.

Another group of essays, keyed to the coloured plates, offers new insights into the visual arts. They include Judith Collard's exposition of Franciscan images in English manuscripts of Matthew Paris' Chronica Maiora and Liber Additamentorum; Hugh Hudson's description of Friar Pietro Teutonico's reliquary diptych in the National Gallery of Victoria; and Claire Renkin's account of Magdalena Steimerin's German translation of Celano's Vita of Clare, in a manuscript colourfully illuminated by Sibylla von Bondorf. These studies culminate in Ursula Betka and Margaret Pont's examination of thirteenth-century Franciscan paintings in Assisi, used as an explanatory context for Arthur Boyd's St Francis tapestries. Designed in 1974, the tapestries were first displayed collectively during the conference, at Newman College in the University of Melbourne.

A final set of essays focuses on post-medieval attempts to live and transmit Franciscan ideals. Maurice Carmody traces themes of reform and division in the Order, which led to its translation, via Ireland, to the founding in 1880 of a convent in Sydney, while James Fitzgerald and Dianne Reilly discuss the part played by Franciscan priest, Patrick Bonaventure Geoghegan, in the civic life of early Melbourne. Josephine Rush MFIC reports the work of Franciscan sisters as inter-faith peace-makers at St Clare's College in Cairo between 2005 and 2009. Ted Witham's essay describes the flourishing of Franciscan values among Australian Anglican tertiaries. Finally, Briege O'Hare OSC narrates the founding in 2004 by Poor Clares of a monastery in Faughart, Dundalk, Ireland, inspired by desert, Celtic and Franciscan eremitical traditions, and embracing the Franciscan values of prayer and poverty. 
In sum, this smorgasbord of Franciscan and Clarissan learning in literature, politics, the visual arts, history, theology and spirituality has much to offer to contemporary readers.

\section{Cheryl Taylor}

School of Arts and Social Sciences,

James Cook University, Townsville 